\title{
PENGARUH DER, FIRM SIZE, NPM, EPS, ROE, DAN EVA TERHADAP NILAI PERUSAHAAN PADA PERUSAHAAN SEKTOR PROPERTI DAN REAL ESTATE YANG TERDAFTAR DI BEI PERIODE 2011-2015
}

\author{
Karina Juwita \\ Program Studi Magister Manajemen Universitas Tarumanagara \\ karinarustandy@yahoo.com
}

Masuk : 17-11-2017, revisi : 04-12-2017 diterima untuk diterbitkan : 04-12-2017

\begin{abstract}
This study aimed to determine the effect of Debt Equity Ratio (DER), Firm Size, Net Profit Margin (NPM), Earning Per Share (EPS), Return on Equity (ROE), and Economic Value Added (EVA) to Price Book Value (PBV). This study is still conducted regards different result of various research. The research was conducted using secondary data. The population in this study are all property and real estate companies listed on the Indonesia Stock Exchange (IDX) of the year 2011-2015. The sampling method applies purposive sampling technique. The data is analysis uses data panel regression analysis. The results of the regression analysis showed that the Debt Equity Ratio and Earning Per Share has no effect on Price Book Value (PBV). Firm Size, Net Profit Margin, and Economic Value Added has negatively effects and significants on Price Book Value (PBV), while the Return on Equity positively affect and significant on Price Book Value (PBV). Adjusted R-Squared value is 0.3043, These results indicate that the variable ability of Debt Equity Ratio (DER), Firm Size, Net Profit Margin (NPM), Earning Per Share (EPS), Return on Equity (ROE), and Economic Value Added (EVA) to explain of Price Book Value is $30.43 \%$ while the remaining $69.57 \%$ is explained by other variables.

Keywords: Debt Equity Ratio (DER), Firm Size, Net Profit Margin (NPM), Earning Per Share (EPS), Return on Equity (ROE), Economic Value Added (EVA), Price Book Value (PBV)
\end{abstract}

\section{PENDAHULUAN}

Tujuan utama perusahaan yang telah go public adalah meningkatkan kemakmuran pemilik atau para pemegang saham melalui peningkatan nilai perusahaan (Salvatore, 2005). Nilai perusahaan sangat penting karena dengan nilai perusahaan yang tinggi akan diikuti oleh tingginya kemakmuran para pemegang saham (Brigham and Gapenski, 2006). Peningkatan nilai saham dan nilai perusahaan biasanya ditandai dengan adanya tingkat pengembalian investasi yang tinggi kepada pemegang saham sehingga nilai tidak hanya mencerminkan kinerja perusahaan tetapi juga menunjukkan prospek perusahaan dalam menjalankan bisnisnya di masa yang akan datang. Nilai perusahaan dapat menggambarkan keadaan perusahaan. Dengan baiknya nilai perusahaan maka perusahaan akan dipandang baik oleh para calon investor (Sri Hermuningsih, 2012).

Debt to Equity Ratio (DER) merupakan penggunaan hutang yang relatif tinggi dibandingkan jumlah modal (ekuitas) yang dimiliki perusahaan dalam melangsungkan aktivitas operasional untuk meningkatkan laba perusahaan. Dengan nilai Debt to Equity Ratio (DER) yang tinggi meningkatkan resiko manajemen perusahaan untuk tidak mampu mengendalikan jumlah hutang dan kewajibannya kepada kreditur. Hal ini menunjukan bahwa perusahaan cenderung untuk meningkatkan hutangnya atas ekspansi perusahaan. Hasil ini konsisten dengan penelitian Binzion dan Salit (1975) dalam Darmawan (2003:24) bahwa terjadi pengaruh positif antara ukuran perusahaan dan hutang.

Menurut Ferry dan Jones (dalam Sujianto, 2001), ukuran perusahaan menggambarkan besar kecilnya suatu perusahaan yang ditunjukkan oleh total aktiva dan jumlah penjualan. Hal 
ini menunjukan bahwa perusahaan cenderung untuk meningkatkan hutangnya atas ekspansi perusahaan. Hasil ini konsisten dengan penelitian Binzion dan Salit (1975) dalam Darmawan (2003:24) bahwa terjadi pengaruh positif antara ukuran perusahaan dan hutang.

Earning Per Share (EPS) adalah rasio yang menunjukkan pendapatan yang diperoleh pada setiap lembar saham. Laba sebuah perusahaan dapat dilihat dari besarnya setiap laba per lembar sahamnya. Semakin tinggi laba bersih yang dihasilkan perusahaan maka akan tinggi pula laba per lembar sahamnya sehingga akan mengakibatkan meningkatnya nilai perusahaan.

Net Profit Margin (NPM) merupakan rasio yang mengukur jumlah laba bersih per nilai dolar penjualan, yang dihitung dengan membagi laba bersih dengan penjualan. Apabila kinerja keuangan perusahaan dalam menghasilkan laba bersih atas penjualan semakin meningkat maka hal ini akan berdampak pada meningkatnya pendapatan yang akan diterima oleh para pemegang saham.

Economic Value Added (EVA) merupakan indikator tentang adanya penciptaan nilai dari suatu investasi. Perusahaan berhasil menciptakan nilai bagi pemilik modal ditandai dengan nilai EVA yang positif karena perusahaan mampu menghasilkan tingkat pengembalian yang melebihi tingkat biaya modal.

Return On Equity (ROE) merupakan alat untuk mengukur kinerja perusahaan menghasilkan rasio yang menunjukkan seberapa besar kemampuan perusahaan menghasilkan laba bersih untuk pengembalian ekuitas terhadap pemegang saham. Menurut Suharli (2006) mengemukakan bahwa dengan baiknya kinerja perusahaan yang salah satunya dicerminkan oleh laba akan meningkatkan pula nilai perusahaan. Semakin baik kinerja perusahaan maka, akan semakin tinggi return yang akan diperoleh oleh investor.

Dari uraian yang sudah dibahas sebelumnya, penulis tertarik untuk melakukan penelitian berjudul: "Pengaruh DER, Firm Size, NPM, EPS, ROE, EVA terhadap Nilai Perusahaan pada Perusahaan Sektor Properti dan Real Estate yang Terdaftar di BEI Periode 2011-2015".

\section{TINJAUAN TEORITIS}

Nilai perusahaan merupakan persepsi investor terhadap perusahaan, yang sering dikaitkan dengan harga saham. Harga saham yang tinggi membuat nilai perusahaan juga tinggi. Tujuan utama perusahaan menurut theory of the firm adalah untuk memaksimumkan kekayaan atau nilai perusahaan (value of the firm) (Salvatore, 2005). Memaksimalkan nilai perusahaan sangat penting artinya bagi suatu perusahaan, karena dengan memaksimalkan nilai perusahaan berarti juga memaksimalkan kemakmuran pemegang saham yang merupakan tujuan utama perusahaan.

Menurut Azis, Mintarti, dan Nadir (2015:86) menyatakan bahwa nilai perusahaan lazim diindikasikan dengan PBV. Brigham dan Houston (2001) menjelaskan bahwa PBV dirumuskan sebagai berikut:

\section{Economic Value Added (EVA)}

$$
\text { PBV }=\frac{\text { Harga Saham }}{\text { Nilai Buku per lembar saham }}
$$

Economic value Added (EVA) mencerminkan laba residu yang tersisa setelah biaya dari seluruh modal, termasuk modal ekuitas telah dikurangkan, sedangkan laba akuntansi ditentukan tanpa menggunakan beban untuk modal ekuitas (E.F Brigham dan J.F Houston, 2006). Perhitungan Economic Value Added (EVA) menurut E.F Brigham dan J.F Houston (2006):

$\mathrm{EVA}=$ NOPAT - Biaya Modal Operasi Setelah Pajak

$=$ EBIT $(1-\mathrm{T})-[($ Total modal operasi yang diberikan oleh investor $) \mathrm{x}$ (persentase biaya modal setelah pajak)]

\section{Menghitung NOPAT (Net Operating Profit After Tax)}

$$
\begin{gathered}
\text { NOPAT }=\text { EBIT }(1-\mathrm{T}) \\
\mathrm{T}=\frac{\text { Beban Pajak }}{\text { Laba Sebelum Pajak }}
\end{gathered}
$$


Keterangan:

EBIT = Laba Sebelum Bunga dan Pajak

$\mathrm{T}=$ Tarif Pajak

\section{Debt to Equity Ratio (DER)}

Menurut Riyanto (2000:33) salah satu rasio yang termasuk dalam rasio solvabilitas atau leverage adalah DER. Rasio ini digunakan untuk mengetahui berapa bagian dari setiap modal sendiri yang dijadikan jaminan untuk keseluruhan hutang perusahaan atau untuk menilai banyaknya hutang yang dipergunakan oleh perusahaan.

Rasio ini dapat dihitung dengan rumus sebagai berikut (Husnan \& Pudjiastuti, 2006:70):

\section{Ukuran Perusahaan (Firm Size)}

$$
\text { Debt to Equity Ratio = } \frac{\text { kewajiban }}{\text { modal sendiri }}
$$

Ukuran perusahaan adalah rata-rata total penjualan bersih untuk tahun yang bersangkutan sampai beberapa tahun. Dalam hal ini penjualan lebih besar daripada biaya variabel dan biaya tetap, maka akan diperoleh jumlah pendapatan sebelum pajak. Sebaliknya jika penjualan lebih kecil daripada biaya variabel dan biaya tetap maka perusahaan akan menderita kerugian (Brigham dan Houston, 2001).

Apabila Ukuran Perusahaan semakin besar dimasa mendatang, maka keuntungan yangdibagi oleh perusahaan diharapkan semakin besar dan diharapkan pula kenaikan pada harga sahamsehingga semakin besar ukuran perusahaan membuat investor untuk berinvestasi di perusahaan tersebut.

\section{Net Profit Margin (NPM)}

NPM dalam Syamsuddin (2001:62) adalah merupakan ratio antara laba bersih (net profit) yaitu penjualan dikurangi dengan seluruh expenses termasuk pajak dibandingkan dengan penjualan. Sawir (2001:18) marjin laba bersih (Net Profit Margin atau Profit Margin On Sales) dirumuskan dengan laba bersih dibagi dengan penjulan, rasio ini mengukur laba bersih setelah pajak terhadap penjualan. Net Profit Margin dapat dihitung dengan rumus:

\section{Earning Per Share (EPS)}

$$
\text { Net Profit Margin = } \frac{\text { Laba Bersih }}{\text { Penjualan }} \times 100 \%
$$

Earning Per Share (EPS) atau laba per lembar saham merupakan alat analisis tingkat profitabilitas perusahaan yang menggunakan konsep laba konvensional (Fabozzi, 1999). Hal ini desebabkan karena EPS dapat menggambarkan prospek earnings perusahaan di masa depan. EPS juga dapat digunakan untuk mengetahui perkembangan suatu perusahaaan dari tahun ke tahun.

\section{Return on Equity (ROE)}

$$
\text { EPS }=\frac{\text { Laba Bersih Setelah Pajak }}{\text { Jumlah Saham Yang Beredar }}
$$

Return on Equity (ROE) merupakan kemampuan suatu perusahaan dengan modal sendiri yang bekerja di dalamnya untuk mengkasilkan laba atau keuntungan (Bambang Riyanto, 2001). Salah satu tujuan perusahaan menjalankan usahanya adalah memakmurkan pemilik perusahaan. Semakin tinggi ROEyang dihasilkan oleh perusahaan maka akan meningkatkan kemakmuran para pemegang perusahaan. Return on Equity dapat diformulasikan sebagai berikut:

$$
\mathrm{ROE}=\frac{\text { Laba Bersih Setelah Pajak }}{\text { Ekuitas }}
$$

\section{METODE PENELITIAN}

Jenis penelitian ini menggunakan metodologi penelitian kuantitatif yaitu metodologi yang berdasarkan data dari hasil pengukuran berdasarkan variabel penelitian yang ada. Objek kajian dari metodologi penelitian kuantitatif adalah ilmu eksak atau ilmu pasti.

Jenis data yang digunakan dalam penelitian ini adalah data sekunder. Data yang digunakan berasal dari laporan keuangan perusahaan yang berupa laporan laba rugi dan neraca 
perusahaan sektor properti dan real estate yang terdaftar di Bursa Efek Indonesia periode 20112015.

\section{Tabel 1}

Teknik Penarikan Sampel

\begin{tabular}{|l|c|}
\hline \multicolumn{1}{|c|}{ Kriteria Penyeleksian Sampel } & Jumlah \\
\hline Jumlah Populasi (Perusahaan Properti yang terdaftar di BEI) & 48 \\
\hline Pengurangan & \\
\hline Data keuangan yang diperlukan tidak lengkap & 13 \\
\hline Perusahaan yang mengalami kerugian selama periode 2011-2015 & 6 \\
\hline Jumlah sampel akhir yang digunakan & 29 \\
\hline Jumlah sampel akhir yang digunakan selama 5 tahun & 145 \\
\hline
\end{tabular}

Sumber: Diolah Sendiri

\section{HASIL PENELITIAN DAN PEMBAHASAN}

\section{Tabel 2}

\section{Hasil Analisis Statistik Deskriptif}

\begin{tabular}{|c|c|c|c|c|c|c|c|}
\hline & DER & EPS & EVA & SIZE & ROE & NPM & PBV \\
\hline Mean & 0.567060 & 141.2848 & 0.786607 & 27.00719 & 0.134083 & 0.405012 & 34.52088 \\
\hline Median & 0.628900 & 33.95000 & 0.567984 & 27.44003 & 0.119981 & 0.278387 & 1.333937 \\
\hline Maximum & 0.903900 & 1308.300 & 3.239672 & 30.08676 & 0.524346 & 5.194385 & 1426.801 \\
\hline Minimum & 0.308600 & 0.380000 & 0.006274 & 22.06459 & 0.001342 & 0.007255 & 0.122362 \\
\hline Std. Dev. & 0.219311 & 271.7431 & 0.647821 & 1.819004 & 0.094605 & 0.598439 & 183.5959 \\
\hline Skewness & 0.211777 & 2.707925 & 1.281037 & 0.784378 & 1.016888 & 5.856417 & 5.908839 \\
\hline Kurtosis & 1.729685 & 9.742380 & 4.564062 & 3.094236 & 4.384770 & 42.75863 & 38.59131 \\
\hline Jarque-Bera & 10.83331 & 451.8630 & 54.43850 & 14.92216 & 36.57523 & 10379.21 & 8496.994 \\
\hline Probability & 0.004442 & 0.000000 & 0.000000 & 0.000575 & 0.000000 & 0.000000 & 0.000000 \\
\hline Sum & 82.22370 & 20486.29 & 114.0581 & 3916.042 & 19.44202 & 58.72679 & 5005.528 \\
\hline Sum Sq. Dev. & 6.926007 & 10633581 & 60.43286 & 476.4637 & 1.288826 & 51.57060 & 4853876. \\
\hline Observations & 145 & 145 & 145 & 145 & 145 & 145 & 145 \\
\hline
\end{tabular}

Sumber: Diolah Sendiri

Diketahui bahwa jumlah sampel sebanyak 145 sampel, yaitu terdiri dari 7 perusahaan sektor properti dan real estate yang telah terdaftar di Bursa Efek Indonesia sejak tahun 2011 dan masih terdaftar sampai dengan akhir masa observasi 2015, serta tidak mengalami kerugian selama periode observasi.

Tabel 3

Hasil Chow-Test menggunakan E-Views 9 (2017)

\begin{tabular}{lrrr} 
Redundant Fixed Effects Tests \\
Pool: Untitled \\
Test cross-section fixed effects \\
\hline \hline Effects Test & Statistic & d.f. & Prob. \\
\hline \hline Cross-section F & 1.870719 & $(29,4314)$ & 0.0032 \\
Cross-section Chi-square & 54.362462 & 29 & 0.0029 \\
\hline \hline
\end{tabular}

Sumber: Diolah Sendiri

Dapat dilihat bahwa nilai profitabilitas Cross-Section Chi-Square adalah sebesar 0.0029, dimana hasil ini lebih kecil dari tingkatt signifikansi $(\alpha)$ yang digunakan dalam penelitian ini, yaitu sebesar 0,05 (5\%). Oleh karena itu model pendekatan yang lebih sesuai ke FE. Jika hasil yang diperoleh menggunakan pendekatan FE, maka harus dilakukan pengujian kembali, yaitu uji Hausman untuk menentukan apakah pendekatan $\mathrm{FE}$ atau random effect (RE) yang digunakan. Apabila nilai profitabilitas Cross-Section Random $<\alpha(5 \%)$ maka pendekatan yang digunakan adalah FE. Namun apabila nilai profitabilitas Cross-Section Random $>\alpha$ (5\%) maka pendekatan yang digunakan adalah RE. 
Tabel 4

Hasil Hausman-Test menggunakan E-Views 9 (2017)

Correlated Random Effects - Hausman Test

Equation: RE

Test cross-section random effects

\begin{tabular}{lrrr}
\hline \hline Test Summary & $\begin{array}{l}\text { Chi-Sq. } \\
\text { Statistic }\end{array}$ & Chi-Sq. d.f. & Prob. \\
\hline \hline Cross-section random & 20.409252 & 6 & 0.0023 \\
\hline \hline
\end{tabular}

Sumber: Diolah Sendiri

Dapat dilihat bahwa nilai profitabilitas Cross-Section Random adalah sebesar 0.0023, dimana hasil ini lebih kecil dari tingkat signifikansi $(\alpha)$ yang digunakan dalam penelitian ini, yaitu sebesar 0,05 (5\%). Oleh karena itu model pendekatan yang lebih sesuai ke FE.

Tabel 5

\begin{tabular}{|c|c|c|c|c|}
\hline \multicolumn{5}{|c|}{$\begin{array}{l}\text { Dependent Variable:PBV } \\
\text { Method: Panel LeastSquares } \\
\text { Date: } 07 / 06 / 17 \text { Time: } 07: 58 \\
\text { Sample: } 20112015 \\
\text { Periods included: } 5 \\
\text { Cross-sections included: } 29 \\
\text { Total panel (balanced) observations: } 145\end{array}$} \\
\hline Variable & Coefficient & Std. Error & $\mathrm{t}$-Statistic & Prob. \\
\hline C & 1655.883 & 206.9670 & 8.000708 & 0.0000 \\
\hline DER & 85.74762 & 61.89455 & 1.385382 & 0.1682 \\
\hline SIZE & -62.28659 & 7.820659 & -7.964366 & 0.0000 \\
\hline NPM & -85.16882 & 23.43437 & -3.634356 & 0.0004 \\
\hline EPS & 0.035503 & 0.066719 & 0.532129 & 0.5955 \\
\hline ROE & 1165.341 & 335.5282 & 3.473153 & 0.0007 \\
\hline EVA & -145.6564 & 57.03119 & -2.553978 & 0.0117 \\
\hline R-squared & 0.333272 & \multicolumn{2}{|c|}{ Mean dependent var } & 34.52088 \\
\hline Adjusted R-squared & 0.304284 & \multicolumn{2}{|c|}{ S.D. dependentvar } & 183.5959 \\
\hline S.E. of regression & 153.1366 & \multicolumn{2}{|c|}{ Akaike info criterion } & 12.94761 \\
\hline Sum squared resid & 3236214 . & \multicolumn{2}{|c|}{ Schwarz criterion } & 13.09131 \\
\hline Log likelihood & -931.7017 & \multirow{2}{*}{\multicolumn{2}{|c|}{$\begin{array}{l}\text { Hannan-Quinn criter. } \\
\text { Durbin-Watson stat }\end{array}$}} & 13.00600 \\
\hline F-statistic & 11.49684 & & & 0.356787 \\
\hline Prob(F-statistic) & 0.000000 & \multicolumn{2}{|c|}{ Durbin-Watson stat } & \\
\hline
\end{tabular}

Sumber: Diolah Sendiri

Dari hasil pengujian diatas, dapat dirumuskan persamaan regresi sebagai berikut:

$$
\begin{gathered}
Y=\beta_{0}+\beta_{1} X_{1}+\beta_{2} X_{2}+\beta_{3} X_{3}+\beta_{4} X_{4}+\beta_{5} X_{5}+\beta_{6} X_{6}+e \\
Y=1655,883+85,74762 \text { DER }+-62,28659 \text { SIZE }+-85,16882 \mathrm{NPM}+0,035503 \mathrm{EPS}+ \\
1165,341 \mathrm{ROE}+-145,6564 \text { EVA }+\mathrm{e}
\end{gathered}
$$

Nilai konstanta pada regresi di atas adalah sebesar 1655,883. Hal ini berarti jika besar DER, firm size, NPM, EPS, ROE, dan EVA adalah nol, maka besarnya nilai perusahaan adalah 1655,883 .

Besarnya profitabilitas ( $p$-value) untuk variabel DER adalah sebesar 0,1682. Nilai tersebut berada diatas tingkat signifikansi $(\alpha)$ yang digunakan dalam penelitian ini, yaitu sebesar 0,05 (5\%). Oleh karena itu dapat disimpulkan bahwa variabel DER tidak memiliki pengaruh yang signifikan terhadap nilai perusahaan.

Besarnya profitabilitas ( $p$-value) untuk variabel firm size adalah sebesar 0,0000. Nilai tersebut berada dibawah tingkat signifikansi $(\alpha)$ yang digunakan dalam penelitian ini, yaitu sebesar 0,05 (5\%). Oleh karena itu dapat disimpulkan bahwa variabel firm size memiliki pengaruh yang signifikan terhadap nilai perusahaan.

Besarnya profitabilitas ( $p$-value) untuk variabel NPM adalah sebesar 0,0004. Nilai tersebut berada dibawah tingkat signifikansi $(\alpha)$ yang digunakan dalam penelitian ini, yaitu sebesar 0,05 (5\%). Oleh karena itu dapat disimpulkan bahwa variabel NPM memiliki pengaruh yang signifikan terhadap nilai perusahaan. 
Besarnya profitabilitas ( $p$-value) untuk variabel EPS adalah sebesar 0,5955. Nilai tersebut berada diatas tingkat signifikansi $(\alpha)$ yang digunakan dalam penelitian ini, yaitu sebesar 0,05 (5\%). Oleh karena itu dapat disimpulkan bahwa variabel EPS tidak memiliki pengaruh yang signifikan terhadap nilai perusahaan. Koefisien regresi untuk variabel DER adalah sebesar 0,035503.

Besarnya profitabilitas ( $p$-value) untuk variabel ROE adalah sebesar 0,0007. Nilai tersebut berada dibawah tingkat signifikansi $(\alpha)$ yang digunakan dalam penelitian ini, yaitu sebesar 0,05 (5\%). Oleh karena itu dapat disimpulkan bahwa variabel ROE memiliki pengaruh yang signifikan terhadap nilai perusahaan.

Besarnya profitabilitas ( $p$-value) untuk variabel EVA adalah sebesar 0,0117. Nilai tersebut berada dibawah tingkat signifikansi $(\alpha)$ yang digunakan dalam penelitian ini, yaitu sebesar 0,05 (5\%). Oleh karena itu dapat disimpulkan bahwa variabel EVA memiliki pengaruh yang signifikan terhadap nilai perusahaan.

Pengujian hipotesis dalam penelitian ini terdiri dari uji-F dan uji-t (parsial). Pengujian hipotesis dilakukan dengan konsep $p$-value dengan membandingkan $\alpha=0,05$ dengan nilai $p$ value. Berikut ini adalah ringkasan dari hasil pengolahan data menggunakan Eviews-9, yaitu sebagai berikut:

Tabel 6

Tabel Hasil Hipotesis

\begin{tabular}{|c|c|c|}
\hline Variabel & Prob. & Ho \\
\hline Bersama-sama & 0,000000 & Ditolak \\
\hline DER & 0,1682 & Tidak Ditolak \\
\hline SIZE & 0,0000 & Ditolak \\
\hline NPM & 0,0004 & Ditolak \\
\hline EPS & 0,5955 & Tidak Ditolak \\
\hline ROE & 0,0007 & Ditolak \\
\hline EVA & 0,0117 & Ditolak \\
\hline
\end{tabular}

Sumber: Diolah Sendiri

Koefisien determinasi digunakan untuk menunjukkan seberapa besar kontribusi pengaruh dari variabel DER, firm size, NPM, EPS, ROE, dan EVA terhadap nilai perusahaan. Nilai koefisien determinasi berada di antara nol dan satu, semakin besar koefisien determinasi (mendekati satu), maka menunjukkan bahwa variabel indenpenden dapat menjelaskan variabel dependen. Hasil pengujian koefisien determinasi dapat dilihat pada tabel 7 , yaitu sebagai berikut:

\section{Tabel 7}

\section{Tabel Hasil Koefisien Determinasi (Adjusted $\mathbf{R}^{2}$ )}

\begin{tabular}{cc}
\hline \hline R-squared & 0.333272 \\
Adjusted R-squared & 0.304284
\end{tabular}

\section{Sumber: Diolah Sendiri}

Berdasarkan hasil pengolahan Eviews-9 pada tabel 4.7. diperoleh nilai koefisien determinasi (Adjusted $\mathrm{R}^{2}$ ) menunjukkan angka sebesar 0,304284. Hasil ini menunjukkan bahwa besarnya kemampuan variabel DER, firm size, NPM, EPS, ROE, dan EVA untuk menjelaskan variabel nilai perusahaan adalah sebesar $30,4284 \%$ dan sisanya $69,5716 \%$ dijelaskan oleh variabel lainnya yang tidak terdapat dalam penelitian ini.

\section{KESIMPULAN DAN SARAN}

Penelitian ini dilakukan dengan tujuan untuk menganalisa hubungan DER, firm size, NPM, EPS, ROE, dan EVA terhadap nilai perusahaan pada perusahaan sektor properti dan real estate yang terdaftar di Bursa Efek Indonesia pada tahun 2011-2015. Berdasarkan hasil penelitian dapat ditarik beberapa kesimpulan sebagai berikut: 
1. Debt to Equity Ratio (DER) tidak memiliki pengaruh yang signifikan terhadap nilai perusahaan pada sektor properti dan real estate yang terdaftar di Bursa Efek Indonesia. Hasil penelitian ini menunjukkan adanya pengaruh positif terhadap nilai perusahaan namun pengaruh DER terhadap nilai perusahaan tidaklah signifikan karena banyaknya hutang tidak akan mempengaruhi nilai perusahaan. Hasil pengujian ini bertentangan dengan penelitian yang dilakukan Barasa (2009) dan Utami (2009) yang menyatakan bahwa DER berpengaruh secara signifikan terhadap nilai perusahaan. Hal itu dikarenakan oleh penggunaan hutang membuat biaya ekuitas bisa naik dengan tingkat yang sama seperti tingkat pendapatan yang dihasilkan dalam pasar modal Indonesia. Teori signaling menyatakan bahwa harga saham itu naik dikarenakan ada corporate action yang memberikan signal ke pasar perusahaan tersebut bagus atau tidak, bukan karena laporan keuangan yang ada di perusahaan.

2. Firm size berpengaruh negatif dan signifikan terhadap nilai perusahaan pada sektor properti dan real estate yang terdaftar di Bursa Efek Indonesia. Hasil firm size yang memiliki hubungan negatif sesuai dengan penelitian Rachmawati dan Hanung (2007). Semakin besar ukuran perusahaan, maka semakin tinggi besar persentase terjadi agency problem. Agency problem menyebabkan biaya keagenan (agency cost) sehingga menyebabkan turunnya profitabilitas pada perusahaan yang berpengaruh negatif pada nilai perusahaan.

3. Net Profit Margin (NPM) berpengaruh negatif dan signifikan terhadap nilai perusahaan. NPM berpengaruh negatif dan signifikan terhadap PBV yang artinya nilai NPM meningkat maka tidak selamanya akan membuat nilai perusahaan juga meningkat. Hal ini dipengaruhi oleh faktor-faktor seperti besarnya beban penjualan (biaya transportasi, biaya administrasi, dll) atau tingginya piutang perusahaan berpengaruh terhadap laba bersih perusahaan.

4. Earning Per Share (EPS) berpengaruh tidak signifikan terhadap nilai perusahaan sesuai dengan penelitian terdahulu yang meneliti perusahaan manufaktur yang terdaftar di BEI pada tahun 2009-2011 (Sukma Mindra dan Teguh Erawati :2014) dimana pada perusahaan properti dan real estate periode tahun 2011-2015 juga berpengaruh tidak signifikan. Hal ini disebabkan karena harga saham saat ini merupakan cerminan dari kinerja sebelumnya, karena di periode yang sama kemungkinan harga itu tercerminnya nanti di periode berikutnya, sehingga hasilnya tidak signifikan.

5. Return on Equity (ROE) berpengaruh positif dan signifikan terhadap nilai perusahaan sesuai dengan penelitian Nova H (2010). Dapat disimpulkan bahwa semakin tinggi ROE yang dicapai oleh suatu perusahaan maka semakin baik dalam memperoleh keuntungan bersih yang mampu diraih oleh perusahaan pada saat menjalankan operasinya. Saat perusahaan mengalami kenaikan keuntungan maka harga saham perusahaan akan ikut naik dan juga peningkatan daya tarik perusahaan menjadikan perusahaan diminati oleh investor yang melihat kemampuan perusahaan dalam mengelola sumber daya yang dimiliki efektif atau tidak. ROE merupakan salah satu faktor yang berpengaruh terhadap nilai perusahaan.

6. Economic Value Added (EVA) berpengaruh negatif dan signifikan terhadap nilai perusahaan sesuai dengan penelitian Zulfia Eka Sari (2013). EVA berpengaruh negatif karena nilai perusahaan menurun sehingga tingkat pengembalian lebih rendah daripada modalnya. EVA negatif juga dapat disebabkan oleh kerugian bersih dalam operasional perusahaan sehingga kerugian yang diperoleh tidak dapat menutup biaya modal rata-rata. Teori signaling menyatakan bahwa harga saham saat ini tercermin oleh informasi sebelumnya sehingga mengukur EVA saat ini data yang dibandingkan adalah laba bersih saat ini sehingga ada ketidaksamaan informasi karena perbedaan waktu saat ini dengan sebelumnya. 
Berdasarkan hasil penelitian, dapat diberikan saran bagi manajemen perusahaan, investor, dan bagi penelitian selanjutnya.

1. Bagi penelitian selanjutnya agar dapat menambah variabel-variabel lain seperti menambah ruang lingkup sampel dan juga periode yang diteliti karena penelitian ini memiliki banyak keterbatasan yang hanya fokus pada perusahaan sektor properti dan real estate saja serta hanya meneliti selama periode 5 tahun yaitu 2011-2015.

2. Bagi manajemen perusahaan memperhatikan Economic Value Added (EVA) karena dapat memberikan dampak negatif terhadap perusahaan apabila tingkat pengembalian lebih rendah daripada modalnya.

3. Bagi investor agar mempertimbangkan faktor-faktor yang mempengaruhi nilai perusahaan karena dapat menunjukkan prospek perusahaan dalam tingkat pengembalian terhadap investasi yang akan dilakukan.

\section{REFERENSI}

Azis, Mintarti, \& Nadir. (2015). Manajemen Investasi: Fundamental, Teknikal, Perilaku Investor, dan Return Saham. Yogyakarta: Deepublish.

Brigham \& Gapenski. (1993). Intermediet Financial and Management $\left(4^{\text {th }}\right.$ ed). United States of America: Horcourt College.

Brigham \& Houston. (2001). Manajemen Keuangan II. Jakarta: Salemba Empat.

Brigham \& Houston. (2006). Dasar-dasar Manajemen Keuangan (Buku 1, Edisi 10, Terjemahan Ali Akbar Yulianto). Jakarta: Salemba Empat.

Fabozzi. (1999). Investmen Manajement (Edisi Dua). New Jersey: Prentice Hall.

Hermuningsih. (2012). Pengaruh profitabilitas, size terhadap nilai perusahaan dengan struktur modal sebagai variabel intervening. Jurnal Siasat Bisnis, 16(2).

Keown, et al. (2004). Dasar-dasar Manajemen Keuangan (Buku 2). Jakarta: Salemba Empat.

Riyanto. (2000). Dasar-dasar Pembelajaran Perusahaan (Edisi III). Yogyakarta: BPFE.

Riyanto. (2001). Dasar-Dasar Pembelanjaan Perusahaan (Edisi Keempat, Cetakan Ketujuh). Yogyakarta: BPFE Yogyakarta.

Salvatore. (2005). Ekonomi Manajerial dalam Perekonomian Global. Jakarta: Salemba Empat.

Sawir. (2001). Analisis Kinerja Keuangan dan Perencanaan Keuangan Perusahaan. Jakarta: PT Gramedia Pustaka Utama.

Suad \& Pudjiastuti. (2006). Dasar-Dasar Manajemen Keuangan (Edisi Kelima). Yogyakarta: UPP STIM YKPN.

Suad. (2000). Manajemen Keuangan Teori dan Penerapan (Edisi Ketiga). Yogyakarta: UPP AMP YKPN.

Sujianto. (2001). Analisis variabel-variabel yang mempengaruhi struktur keuangan pada perusahaan manufaktur yang go public di Bursa Efek Jakarta. Jurnal Ekonomi dan Manajemen, 2(2).

Syamsudin. (2001). Manajemen Keuangan Perusahaan: Konsep Aplikasi dalam Perencanaan, Pengawasan, dan Pengambilan Keputusan (Edisi Baru). Jakarta: PT. Raja Grafindo Persada 